J. Product. \& Dev., 22(2): 267- 285 (2017)

\title{
THE EFFECT OF FOLIAR SPRAYING ROYAL JELLY ON GROWTH AND FRUITING OF ZEBDA MANGO TREES GROWN UNDER ASWAN REGION CONDITIONS
}

\author{
Mohamed A. El-Sayed *; Ahmed Y. Mohamed ** and Fatma El-Zahraa \\ A. Mohamed* \\ * Hort. Dept. Fac. of Agric. Minia Univ., Egypt \\ ** Tropical Fruits Res. Dept. Hort. Res. Instit., ARC, Giza, Egypt \\ E.mail: faissalfadel@yahoo.com
}

\begin{abstract}
During 2015 and 2016 seasons, Zebda mango trees treated once (at the beginning of growth), twice (at growth the beginning and again just after fruit setting), or thrice (at growth start, just after fruit setting and at one month later) with Royal Jelly at 0.0125 up to $0.05 \%$. The effects of Royal jelly treatments on growth and fruiting of the trees were investigated.

Treating the trees once, twice, or thrice with Royal Jelly at 0.0125 up to $0.05 \%$ caused a remarkable promotion on all growth characteristics, leaf pigments and various nutrients, yield as well as both physical and chemical characteristics of the fruits compared with the control treatment. There was a gradual promotion on growth traits, nutrients, yield and fruit quality with increasing concentrations and frequencies of application of Royal Jelly. The differences between the two higher concentrations (0.025\& $0.05 \%)$ and frequencies (twice $\&$ thrice) as promotion on these parameters were insignificantly effected in both seasons.

Conclusively, the best results with regard to yield and fruit quality of Zebda mango trees grown under Aswan region conditions were obtained when the trees sprayed twice at growth start and again just after fruit setting with Royal Jelly at 0.025\%.
\end{abstract}

Keywords: Royal Jelly, yield, fruit quality, Zebda mangoes.

\section{INTRODUCTION}

Nowadays, many efforts will be established for finding out the best horticultural practices that are responsible for enhancing yield and fruit quality of the prime mango cv Zebda.

Using of natural extracts especially Royal Jelly was araised. Rare literatures are available about the impact of Royal Jelly on the horticultural 
crops. Royal Jelly is secreted from the heads of queen bees from pollens, water and honey mixed with saliva, hormones, and vitamins. It contains higher amounts of amino acids, proteins, lipids, fructose, glucose, sucrose, minerals such as $\mathrm{K}, \mathrm{Mg}, \mathrm{Ca}, \mathrm{Fe}, \mathrm{P}, \mathrm{S}, \mathrm{Mn}$ and $\mathrm{Si}$ and vitamins such as $\mathrm{B}_{1} \& \mathrm{~B}_{2} \& \mathrm{~B}_{5}$ \& $\mathrm{B}_{6} \& \mathrm{~B}_{8} \& \mathrm{~B}_{9}, \mathrm{~B}_{12}, \mathrm{~A}, \mathrm{C}, \mathrm{D}, \mathrm{K}$ and $\mathrm{E}$. Also, it contains gonadortophic and sex hormones (Hyel 1951 and Nation and Robinson, 1971).

Previous studies showed that using Royal Jelly had an announced promotion on growth and fruiting of different horticultural fruit crops (ElMaziny and Hassan, 1990; El- Shaikh, 2010 ; Rekaby, 2013; Al- Wasfy, 2013 , Moustafa, 2013; Ahmed and Habasy- Randa, 2014; Gad El- Kareem and Abada, 2014 and Abada and Ahmed- Basma,2015; Wassel et al., 2015 and Abdelaziz et al., 2015).

Therefore, the main target of this study was elucidating the effect of different concentrations and frequencies of application of Royal Jelly on some vegetative growth characteristics, leaf chemical composition, fruit setting, yield and fruit quality of Zebda mango trees grown under Aswan region conditions.

\section{MATERIALS AND METHODS}

This investigation was conducted during the two consecutive seasons of 2015 and 2016 on thirty 15-years old Zebda mango trees onto polyembyonic seedling rootstock. The trees are grown in a Private mango orchard located at Harbbiab Island, Drao district, Aswan Governorate. The used Zebda mango trees with uniform in vigour were planted at $5 \times 5$ meters apart. The soil texture of the tested orchard is silty clay with a water table depth not less than two meters. Surface irrigation system was followed.

The results of orchard soil analysis (according to Wilde et al., 1985) are shown in Table 1.

The selected trees received the regular agricultural and horticultural practices which were followed in the orchard. This experiment included the following ten treatments from spraying Royal jelly, at different concentration and frequencies.

1) Control (trees treated with water).

2) Royal Jelly once at the beginning growth (1st week of March) at $0.0125 \%$.

3) Royal Jelly twice at the beginning growth and again just after fruit setting (last week of Apr.) at $0.0125 \%$.

4) Royal Jelly thrice at the same two previous dates and at one month later (last week of May) at $0.0125 \%$. 
Table (1): Mechanical, physical and chemical analysis of the tested orchard soil.

\begin{tabular}{|c|c|}
\hline \multicolumn{2}{|l|}{ Particle size distribution: } \\
\hline Sand $\%$ & 6.1 \\
\hline Silt \% & 56.7 \\
\hline Clay \% & 37.2 \\
\hline Texture & Silty clay \\
\hline $\mathrm{pH}(1: 2.5$ extract $)$ & 7.35 \\
\hline EC ( $1: 2.5$ extract $)\left(\mathrm{mmhos} / \mathrm{Icm} / 25^{\circ} \mathrm{C}\right)$ & 0.59 \\
\hline O.M. \% & 2.39 \\
\hline $\mathrm{CaCO}_{3} \%$ & 1.45 \\
\hline Total N \% & 0.18 \\
\hline Available P (ppm, Olsen) & 9.0 \\
\hline Available K (ppm, ammonium acetate) & 5.01 \\
\hline Available $\mathrm{Mg}$ (ppm) & 115.0 \\
\hline Available S (ppm) & 7.11 \\
\hline \multicolumn{2}{|c|}{ Available EDTA extractable micronutrients (ppm) } \\
\hline $\mathrm{Zn}$ & 1.49 \\
\hline $\mathrm{Fe}$ & 12.11 \\
\hline $\mathrm{Mn}$ & 9.39 \\
\hline
\end{tabular}

5) Royal Jelly once at the beginning growth (1st week of March) at $0.025 \%$.

6) Royal Jelly twice at the beginning growth and again just after fruit setting (last week of Apr.) at $0.025 \%$.

7) Royal Jelly thrice at the same two previous dates and at one month later (last week of May) at $0.025 \%$.

8) Royal Jelly once at the beginning growth (1st week of March) at $0.05 \%$.

9) Royal Jelly twice at the beginning growth and again just after fruit setting (last week of Apr.) at $0.05 \%$.

10) Royal Jelly thrice at the same two previous dates and at one month later (last week of May) at $0.05 \%$.

Royal jelly was stored at $0.0^{\circ} \mathrm{C}$ till application. It was solubilized in cold water before use (Table 3 ). Triton $\mathrm{B}$ as a wetting agent a $0.05 \%$ was added to all spraying solutions (each tree needs about $25 \mathrm{~L}$ solutions). Spraying was done till runoff. The untreated trees sprayed with water containing Triton B. 
Table (2): Chemical Analysis of Royal Jelly (Townsend and Lucas, 1966).

\begin{tabular}{|c|c|}
\hline Constituents & "Values (mg/ 100 g F.W.) \\
\hline Water & 65.3 \\
\hline Dry matter & 34.7 \\
\hline Proteins & 48.2 \\
\hline Carbohydrate & 37.8 \\
\hline Lipids & 10.4 \\
\hline Ash & 2.0 \\
\hline Sugar & 23.0 \\
\hline Glucose & 4.0 \\
\hline Fructose & 4.0 \\
\hline Sucrose & 5.0 \\
\hline $\mathrm{K}$ & 220 \\
\hline $\mathrm{Mg}$ & 105 \\
\hline $\mathrm{Ca}$ & 112 \\
\hline $\mathrm{Fe}$ & 50 \\
\hline $\mathrm{P}$ & 118 \\
\hline $\mathrm{S}$ & 44 \\
\hline $\mathrm{Mn}$ & 32 \\
\hline $\mathrm{Si}$ & 5 \\
\hline Vitamins $\mathrm{B}_{1}$ & 0.4 \\
\hline Vitamins $\mathrm{B}_{2}$ & 0.3 \\
\hline Vitamins $\mathrm{B}_{5}$ & 0.4 \\
\hline Vitamins $\mathrm{B}_{6}$ & 0.3 \\
\hline Vitamins $\mathrm{B}_{8}$ & 0.3 \\
\hline Vitamins $\mathrm{B}_{9}$ & 0.4 \\
\hline Vitamins $\mathrm{B}_{12}$ & 0.3 \\
\hline $\mathrm{A}$ & 0.4 \\
\hline $\mathrm{C}$ & 0.9 \\
\hline $\mathrm{D}$ & 0.5 \\
\hline $\mathrm{K}$ & 0.4 \\
\hline $\mathrm{E}$ & 0.3 \\
\hline Essential amino acids & 1100 \\
\hline
\end{tabular}

This study was statistically analyzed using Randomized Complete Block Design (RCBD) in which the experiment included ten treatments and 
each treatment was replicated three times, one tree per each. During both seasons, the following measurements were recorded:

1- Some vegetative growth characteristics namely shoot length $(\mathrm{cm}$.$) , length$ and width of leaf, leaf area (Ahmed and Morsy, 1999), number of leaves per shoot and shoot thickness $(\mathrm{cm})$ in the spring growth cycle.

2- Leaf chemical composition including chlorophylls a \& b, total chlorophylls and total carotenoids (as mg / 100 g F.W.) (Von-Wetsttein, 1957 and Hiscox and Isralstam, 1979) as well as leaf mineral content namely $\mathrm{N}, \mathrm{P}, \mathrm{K}, \mathrm{Mg}, \mathrm{Ca}, \mathrm{Zn}, \mathrm{Fe}$ and $\mathrm{Mn}$ (on dry weight basis) (Cottenie et al., 1982, Summer, 1985 and Wilde et al., 1985).

3- Number of retained fruits/ panicle.

4- Yield / tree (kg.) and per feddan (tons) as well as number of fruits / tree.

5- Some physical and chemical characteristics of the fruits namely weight (g.), height, diameter and thickness $(\mathrm{cm}$.) of fruit, flesh \%, edible to nonedible portion of fruit, T.S.S.\%, total acidity \% ( as a citric acid/100 g pulp), total and reducing sugars \%, (Lane and Eynon, 1965), total fiber and vitamin $\mathrm{C}$ content (mg/ $100 \mathrm{ml}$ juice) (A.O.A.C., 2000).

All the obtained data during the course of this study in the two successive seasons, 2015 and 2016 were tabulated and statistically analyzed. The difference between various treatment means were compared using new L.S.D. at 5\% (according to Mead et al., (1993) and Rangaswamy (1995).

\section{RESULTS}

\section{1- Some vegetative growth characteristics:}

It is evident from the obtained data in Table (3) that, the foliar spray of treating Zebda mango trees once (at growth stages), twice (the beginning growth and again just after fruit setting) or thrice (the same two previous dates and at one month later) with Royal Jelly at 0.0125 up to $0.05 \%$ were significantly stimulated the six tested growth aspects compared to the control. The significantly maximum values of shoot length $(27.8 \& 26.2$ $\mathrm{cm})$, number of leaves / shoot (17.7 \& 17.4 leaf), leaf length $(28.1 \& 28.0$ $\mathrm{cm})$, leaf width $(6.3 \& 6.4 \mathrm{~cm})$, leaf area $\left(122.9 \& 124.7 \mathrm{~cm}^{2}\right)$ and shoot thickness $(0.89 \& 0.90 \mathrm{~cm})$ were observed on the trees that received Royal Jelly three times at $0.05 \%$ during both seasons, respectively, without significant differences with those sprayed by Royal Jelly two times at $0.05 \%$ and those sprayed with Royal Jelly at 0.025 two or three times. The lowest values were recorded on the untreated trees. These results were true during both seasons. 
MOHAMED EL-SAYED et al. 
Thus, from the economical point of view, it is advised to use Royal jelly twice at 0.025 to obtain the highest vegetative growth characteristics

The promoting effect of Royal Jelly on growth characteristics might be attributed to its higher content of carbohydrates, soluble sugars, proteins, amino acids, vitamins B, A, C, D, K, E, most macro and micronutrients and antioxidants (Hyel, 1951; Townsend and Lucas, 1966 and Nation and Robinson, 1971). These essential components effectively enhanced the biosynthesis of organic foods and cell division, consequently encourages the development of new plant organs.

These results are in agreement with those obtained by Al- Wasfy (2013) on Flame seedless grapevines, Ahmed and Habasy- Randa (2014) on Washington navel orange trees Gad El- Kareem and Abada (2014) on Flame seedless grapevines, Abada and Ahmed- Basma (2015) on Superior grapevines, Abdel -Aziz et al., (2015) on Ewaise mango trees and Wassel et al., (2015) on Flame seedless grapevines.

\section{2- Leaf chemical composition:}

It is clear from the data in Tables $(4 \& 5)$ that the effect of one, two or three sprays of Royal Jelly at 0.0125 to $0.05 \%$ was significantly and very effective in enhancing leaf (photosynthetic pigments chlorophylls a \& b, total chlorophylls and total carotenoids), $\mathrm{N}, \mathrm{P}, \mathrm{K}, \mathrm{Mg}, \mathrm{Ca}, \mathrm{Zn}, \mathrm{Fe}$ and $\mathrm{Mn}$ over the control treatment. There was a gradual promotion on these leaf pigments with increasing concentrations and frequencies of application of Royal Jelly. Significant differences were observed among the ten Royal Jelly treatments except between the higher two concentrations and frequencies of application. The highest values of chlorophyll a $(7.2 \& 7.6$ mg / 100 g F.W.), chlorophyll b ( 3.1 \& $3.4 \mathrm{mg} / 100$ g F.W.), total chlorophylls (10.3 \& $11.0 \mathrm{mg} / 100 \mathrm{~g} \mathrm{~F}$.W.) and total carotenoides $(2.7 \&$ $2.9 \mathrm{mg} / 100$ g F.W.) N ( $1.92 \& 1.92 \%), \mathrm{P}(0.26 \& 0.27 \%), \mathrm{K}(1.39 \&$ $1.43 \%), \mathrm{Ca}(3.13 \& 3.16 \%), \mathrm{Mg}(0.73 \& 0.73 \%), \mathrm{Mn}(57.2 \& 59.3$ ppm), Fe ( $63.8 \& 60.5 \mathrm{ppm})$ and $\mathrm{Zn}(71.5 \& 69.5 \mathrm{ppm})$ were recorded on the trees sprayed three times with Royal Jelly at $0.05 \%$ during both seasons, respectively, without significant differences with those sprayed by Royal Jelly two times at $0.05 \%$ and those sprayed with Royal Jelly at 0.025 two or three times. The untreated trees produced the lowest values. Similar results were announced during 2015 and 2016 seasons.

Therefore, from the economical point of view, it is recommended to use Royal jelly twice at 0.025 to achieve the highest content of plant pigments and nutrients in the leaves. 


\section{3- Flowering aspects:}

Data in Table 6 show that spraying of Royal Jelly at the used concentrations and frequencies resulted in significant promotion on the five flowering aspects namely panicle length, number of panicles/ tree, percentages of male and perfect flowers and number of flowers per panicle over the control treatment. There was a gradual promotion on these flowering aspects with increasing concentrations and frequencies of application of Royal Jelly. The best results with regard to flowering aspects were obtained by treating the trees three times with Royal Jelly at $0.05 \%$, without significant differences with those sprayed by Royal Jelly two times at $0.05 \%$ and those sprayed with Royal Jelly at 0.025 two or three times. Thus, from the economical point of view, it is advised to use Royal jelly twice at 0.025 to obtain acceptable flowering aspects of Zebda mango trees grown under Aswan region condition. Under such promised treatment, number of panicles per tree reached 161 and 163 during both seasons, respectively. Untreated trees produced 141 and 139 panicles during 2015 and 2016 seasons, respectively.

\section{4- Percentage of initial fruit setting and yield per tree and per feddan:}

Data in Table (7) clear that the percentage of initial fruit setting, fruit yield per tree and per feddan were significantly promoted by spraying Zebda mango trees with the used concentrations and frequencies of Royal jelly as compared to the control. The maximum values of these tested characteristics were recorded on the trees received three sprays of Royal jelly at $0.05 \%$, without significant differences with those sprayed by Royal Jelly two times at $0.05 \%$ and those sprayed with Royal Jelly at 0.025 two or three times.

Thus, from the economical point of view, it is recommended to use Royal jelly twice at 0.025 to obtain acceptable yield of Zebda mango trees grown under Aswan region condition. Under such promised treatment, the initial fruit setting reached (48.0 and $50.0 \%)$, the number of fruit per tree (322 and 326 fruit), yield per tree (111.4 and $114.4 \mathrm{Kg}$.$) and yield per$ feddan (17.8 and 18.3 tons) as compared with the untreated trees which produced the lowest values during both seasons, respectively. These results were true during both seasons.

\section{5- Some physical and chemical characteristics of the fruits}

It is noticed from the obtained data in Tables ( $8 \& 9$ ) that, Zebda mango trees were sprayed with Royal Jelly once, twice or thrice at 0.0125 to $0.05 \%$ had significantly effect on fruit on quality of the fruits in terms of increasing weight, height, diameter and thickness of fruit, flesh \%, edible to 
non edible portions, T.S.S.\%, total and reducing sugars $\%$ and vitamin C content and decreasing total acidity and total fibre over the control treatment. The promotion on both physical and chemical characteristics was associated with increasing concentrations and frequencies of Royal Jelly. Significant differences on all the investigated characteristics among all Royal Jelly treatments except among the higher two concentrations, and frequencies of application.

From economical point of view, it is suggested to use Royal Jelly twice at $0.025 \%$. Under such promised treatment, the best results with regard to quality of the fruits were obtained. Unfavorable effects on fruit quality were attributed to using Royal Jelly at $0.0 \%$ (control). These results were true during both seasons.

\section{DISCUSSION}

The higher content of Royal Jelly from Proteins, Carbohydrate, Lipids, Ash, Sugar, Glucose, Fructose, Sucrose, K, Mg, Ca, Fe, P, S, Mn, Si, Vitamins $\mathrm{B}_{1}, \mathrm{~B}_{2}, \mathrm{~B}_{5}, \mathrm{~B}_{6}, \mathrm{~B}_{8}, \mathrm{~B}_{9}, \mathrm{~B}_{12}, \mathrm{~A}, \mathrm{C}, \mathrm{D}, \mathrm{K}$ and $\mathrm{E}$ and Essential amino acids and hormones (Hyel, 1951; Townsend and Lucas, 1966 and Nation and Robinson, 1971). surely reflected on enhancing cell division as well as the biothensis of pigments and most organic nutrients, consequently improving flowering and fruit setting. The present benficial effects of Royal Jelly on growth, nutritional status of the trees flowering and fruit setting certainly with accompanied with enhanced yield and fruit quality.

These results are in agreement with those obtained by Al- Wasfy (2013) on Flame seedless grapevines, Ahmed and Habasy- Randa (2014) on Washington navel orange trees Gad El- Kareem and Abada (2014) on Flame seedless grapevines, Abada and Ahmed- Basma (2015) on Superior grapevines, Abdel -Aziz et al., (2015) on Ewaise mango trees and Wassel et al., (2015) on Flame seedless grapevines.

Conclusively, under the experimental and similar conditions, it is suggested to spray Zebda mango trees twice at growth start and again just after fruit setting with Royal Jelly at $0.025 \%$ for promoting yield and fruit quality.

\section{REFERENCES}

Abada, M.A.M. and Ahmed- Basma, R. (2015): The beneficial effects of using Royal jelly, arginine and treptophane on fruiting of Superior grapevines. $2^{\text {nd }}$ Inter. Conf. on Hort. Crops., 15- 18 March , 2015 (ICHC, 2015). 
Abdelaziz, F.H.; Mohamemed, M.A. and Abd El- Rady, S.E.M.(2015): Relation of fruiting in Ewaise mango trees to foliar application or Royal Jelly, magnesium and boron. World Rural Observations. 7(2):85-92.

Ahmed, F.F. and Habasy- Randa E.Y. (2014): Productive performance of Washington Navel orange trees in relation to foliar application of Barley seed sprout and Royal Jelly World Rural Observations, 6(4): 109-114

Ahmed, F. F. and Morsy, M. H. (1999): A new method for measuring leaf area in different fruit species. Minia J. of Agric. Res. \& Develop., Vol. (19) pp 97-105.

Al- Wasfy, M.M. (2013): Response of Sakkoti date palms to foliar application of Royal Jelly, silicon and vitamins B. J. of Amer. Sci., 9 (5): 315-321.

A. O. A. C. (2000) Association of Official Agricultural Chemists . Official Methods of Analysis. $17^{\text {th }}$ Ed Published by A. O. A. C. Washington, D. C. (U.S.A.). pp. 490-510.

Cottonie, A; Verloo, M.; Velghe, M. and Camerlynck, R. (1982): Chemical Analysis of Plant and Soil. Ghent, Belgium, Laboratory of Analytical and Agro-Chemistry. State Univ. pp. 200 - 210.

El- Maziny, M.Y. and Hassan, M.N.M. (1990): Effect of Royal Jelly, vitamin B complex and ethrel on the productivity of cucumber. Minia J. Agric. Res. Des. Dev., 12(3):1901-1909.

El- Shaikh, Kh. A.A. (2010): Growth and yield of some cucumber cultivars as affected by plant density and Royal Jelly application. J. of Hort. Sci. \& ornamental Plants, 2(2):131-137.

Gad El- Kareem, M.R. and Abada, M.A.M. (2014): Trials for promoting productivity of Flame seedless grapevines. J. Biol. Chem. Environ. Sci., 9 (1): 35-46.

Hyel, H.L. (1951): An observation suggesting the presence of gonadotrofic hormone in Royal Jelly. Science, 89: 590-591.

Hiscox, A. and Isralstam, B. (1979): A method for the extraction of chlorophyll from leaf tissue without maceration. Can. J. Bot.,57: 1332-1334.

Lane, H. and Eynon, L. (1965): Determination of reducing sugars by means of Fehlings solution with methylene blue as indicator. A.O.A.O Washington D.C., U.S.A.

Mead, R.; Currnow, R.N. and Harted, A.M. (1993): Statistical Methods in Agricultural and Experimental Biology. Second Ed. Chapman: Hall. London, pp. 10- 20. 
Moustafa, H.E.B. (2013): Enhancing growth and nutritional status of Chorisia spociosa seedlings by using Royal Jelly and silicon. Minia J. of Agric. Res. \& Develop., 33(1): 83-95.

Nation, J.L. and Robinson, E.AS. (1971): Concentration of some major and trace elements in honey bee, Royal jelly and pollen . J. Apic. Res., 10(1): 35-43.

Rangaswamy, R. (1995): Randomized Complete Block Design. In A text Book of Agricultural Statistics. New Age International Publishers, pp. 281- 309.

Rekaby, A.F. (2013): Improving the productivity of coriander plants by the use of some non-traditional treatments. Ph,. D, Thesis Fac. of Agric. Minia Univ. Egypt.

Summer, M.E. (1985): Diagnosis and Recommendation Integrated System (DRIS) as a guide to orchard fertilization. Hort. Abst. , 55 (8); 7502.

Townsend, G. and Lucas, C. (1966): The chemical natural of Royal jelly. Biochemical. J., 34:1115-1162.

Von- Wettstein, D. V. C. (1957): Clatal und der Sumbmikro Skopisne Pormwechsel de Plastids. Experimental Cell Research, 12:427.

Wassel, A.M.; Gobara, A.A. and Hussien, M.A.M. (2015): Effect of spraying Royal Jelly on productivity of Flame seedless grapevines. World Rural Observations, 7(4): 51-59.

Wilde S. A.; Corey, R. B.; Lyer, I. G. and Voigt, G. K. (1985): Soil and Plant Analysis for Tree Culture. $3^{\text {rd }}$ Oxford \& $113 \mathrm{H}$ publishing Co., New Delhi, pp. 1 - 218. 
تأثير رش الغذاء الملكى على النمو والاثمار في أشجار الماتجو الزبدة النامية تحت ظروف منطقة اسوان

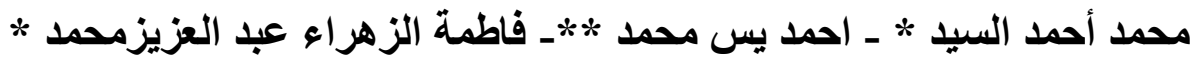

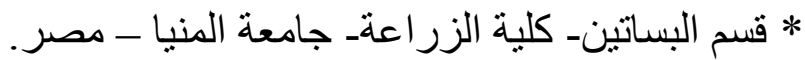

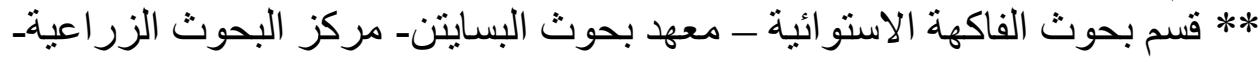

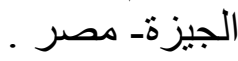

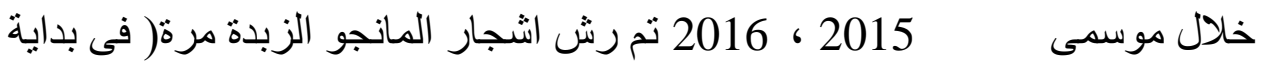

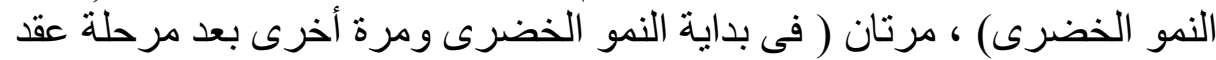

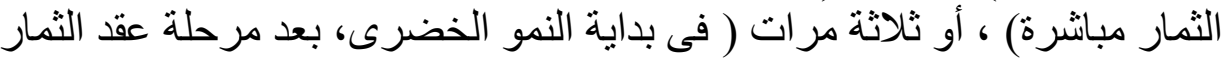

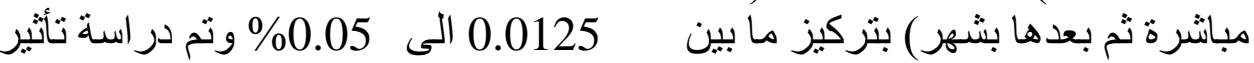

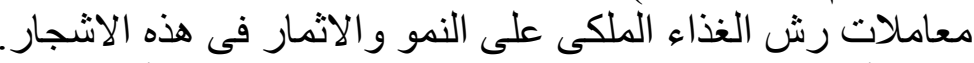

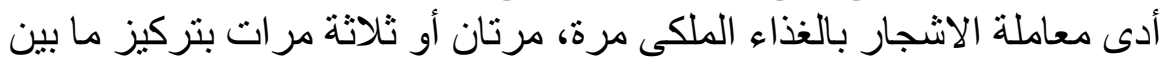

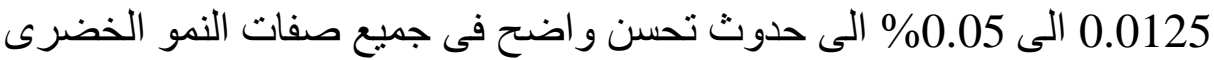

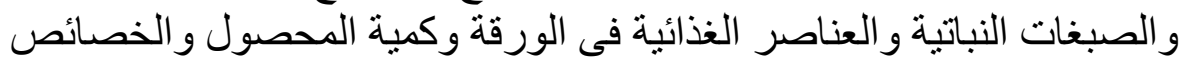

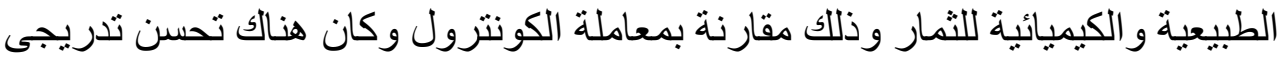

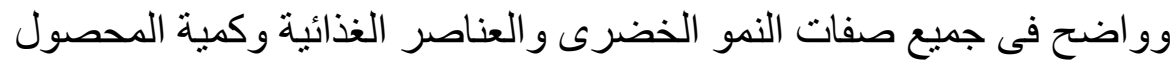

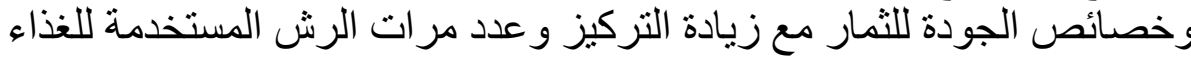

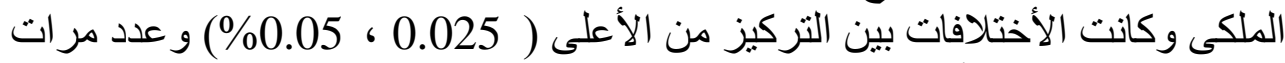
الرش الاكثر (مرتان أو ثلاثة درات) كتنشيط لهذه الصفات غين التير معنوية في كل التوصية:ة: أمكن الحصول على أفضل النتائج بخصوص كمية المحصول وخصائص الجودة فى أشجار المانجو الزبدة عند رش الاشئ الشجار بالغذاء الملكى مرتان في بداية

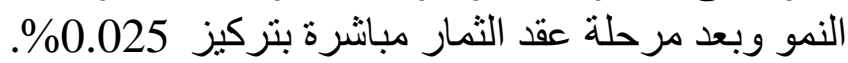


MOHAMED EL-SAYED et al. 